\title{
Effect of Economic Variables on the Financial Performance of Listed Firms Manufacturing Consumers Goods in Nigeria
}

\author{
Idaka Sunday Egbe ${ }^{1, *}$, Ugwoke Robinson Onuora ${ }^{2}$, Ajuh Ali Iteh ${ }^{2}$, Edith O. Onyeanu ${ }^{2}$ \\ ${ }^{1}$ Department of Accounting, University of Calabar, Calabar, Nigeria \\ ${ }^{2}$ Department of Accountancy, University of Nigeria Nsukka, Enugu Campus, Nigeria
}

Received July 21, 2021; Revised October 10, 2021; Accepted October 21, 2021

\section{Cite This Paper in the following Citation Styles}

(a): [1] Idaka Sunday Egbe, Ugwoke Robinson Onuora, Ajuh Ali Iteh, Edith O. Onyeanu, "Effect of Economic Variables on the Financial Performance of Listed Firms Manufacturing Consumers Goods in Nigeria," Universal Journal of Accounting and Finance, Vol. 9, No. 6, pp. 1235 - 1246, 2021. DOI: 10.13189/ujaf.2021.090603.

(b): Idaka Sunday Egbe, Ugwoke Robinson Onuora, Ajuh Ali Iteh, Edith O. Onyeanu (2021). Effect of Economic Variables on the Financial Performance of Listed Firms Manufacturing Consumers Goods in Nigeria. Universal Journal of Accounting and Finance, 9(6), 1235 - 1246. DOI: 10.13189/ujaf.2021.090603.

Copyright $\bigcirc 2021$ by authors, all rights reserved. Authors agree that this article remains permanently open access under the terms of the Creative Commons Attribution License 4.0 International License

\begin{abstract}
The study analyzes the effect of economic variables on the financial performance of listed firms manufacturing consumer goods in Nigeria. The researchers adopted the Ex-post facto research design and Ordinary Least Square multiple regression analysis for estimation of the equations. The population comprises 20 listed consumer goods manufacturing companies, and total sample of 13 firms, the data covered 17 years' financial reports. The sample was determined using the elimination method and purposive sampling techniques. We found strong correlation between CPI, interest, exchange rates and net asset per share. CPI has significant effect on NAPS and there is short run relationship based on the coefficients ARDL, exchange and interest rates showed no significant effect on NAPS. The economic implication of the result based on the CPI is that consumers are paying more due to the rise in the level of inflation, firms adjust their profit margin to cushion the effect, and $1 \%$ rise in interest and exchange rates result to decline in NAPS. The researchers recommended that government should provide enabling environment for business to thrive by providing moderate interest rate to manufacturing firms, and encourage the demand for made-in-Nigeria to strengthen the value of the Naira to compete well with foreign currencies in the international market.
\end{abstract}

Keywords Consumer Price Index, Interest Rate, Exchange Rate, Net Asset Per Share, Consumer Goods,
Financial Performance

\section{Introduction}

Companies operating in Nigeria that are into the production of consumer goods play crucial roles in accelerating economic activities. As such, their services to their numerous customers are indispensable. They serve as the backbone that drives the economic, because they ameliorate economic activities by making both consumables and non-consumables products available to both individuals and corporate entities Sanusi [1]. The performance indices namely; return on asset (ROA), return on equity (ROE), net asset per share (NAPS), earnings per share (EPS) etc. of are crucial variables because local and foreign investors hold the view that if an economic is developing, such economic should be a producing economic. The economic is considered good if key factors such as; money supply, interest, exchange and unemployment rates, tax policies, consumer price index, etc. are moderately control through formulation and implementation of policies that will encourage foreign and local investors to invest in key sectors of an economy (World Bank Group [2]; Broadstock, Shu \& Xu [3]. The economic situation for years had caused a lot decrease on 
firms' assets due to low capital investment (Umar, Jaleel \& Shamshair [4]. Since 2016, 2017, 2018, 2019, 2020 and 2021 , the inflation rate is on the increase and the major cause of the increase in consumer price index. The prices of food items rose to 17.4 percent in 2019 which was considered the biggest increase in four years; the resultant effect is reduction net asset because price increase might not cushion the effect Oso [5]. Food prices accounted for 60 percent of the increase in total inflation as at 2020 which is obvious indication that the end users pay more for consumable products.

For decades, the perennial volatility in exchange rate which emanates from various policies occurred due to the removal of the fixed exchange rate with the British pounds, and the floating of the currency in 1986 resulted to policy imbalance that almost cripple Nigerian economy between 1982 and 1985 periods. The economic and political policies that underpinned the exchange rate policies within each of these epochs, adversely impacted on the activities of manufacturing companies in Nigeria Agubata \& Odubuasi [6]. To curb the negative effect of interest rate which was considered key economic variable that also impeded efficient operation of firms, the apex bank used the Monetary Policy Rate to exercise some controls in the movement of interest rate in the Nigerian economy Ogunbiyi and Ihejirika [7]. Despite all these, interest, exchange rates and consumer price index which is a measure of inflation has continued to be on the increase because of the frequent alteration of policies from one administration to another. The introduction of the maximum lending rate bench mark in 1993 resulted to unprecedented increase in the rate of interest, with rising inflation rate which adversely affected many firms Ogunbiyi \& Ihejirika [7].

Exchange, inflation and Interest rates deserve careful attention in developing countries because little increase in the rates are very sensitive and controversial, because of the kind of structural adjustments and transformation required to tackle the economic uncertainties in the system. Countries around the globe strive to maintain good economic policies because having a producing sector is very key, and that makes the economic a progressing economic due to the positive impact of manufacturing firms on economic activities in terms of job creation and value added to Gross Domestic Product and exportation. The low production capacity frequently experience in the manufacturing sector is caused by increased interest rate, and appreciation in the dollar value against the naira which for decades has created big gap between the value of the Naira Adibiyi [8]; Rasheed [9]. The inconsistencies in the implementation of budget especially the capital projects that could have help mitigate the negative impact of the economic variables is one aspect that has not been well addressed to cushion the perennial economic issues confronting manufacturing companies in Nigeria through creation of enabling environment Okafor [10].
The existence of corporate institutions like the manufacturing firms with very strong assets are indispensable for any country that intend to make meaningful progress because the returns on their stock add to their net worth which enables management to make investment in capital assets for expansion and to take advantage of innovations Islam, [11]. Despite the fact that these organizations are wealth maximization oriented, investors considered the value of per share in terms of the net asset as a key variable for decision making purpose. Onakoya [12]; Amakom [13] who opined that improve in the manufacturing sector through service liberalization plays significant impact on growth. The economic environment contributes to the success of firms which can only be possible if there are well-articulated economic policies that will serve as cushion to the uncontrollable economic forces. Inadequate measures by government in terms of policies are capable of causing firms to loss considerable amount of their assets thereby causing drastic decline in their net asset per share Mintzberg, et al [14].

Obviously, no country can discuss the issue of economic growth without first looking at some key variables to determine how they impact on the performance of corporate organizations which are considered the engine of any society that is striving towards the path of economic development. Many scholars hold the view that for economy to move towards the path of prosperity, such economic must be a producing economic that depend heavily on import to drive its activities. Proponents of moderate economic variables as a panacea for better improvement in the manufacturing sector include (Agubata and Odubuasi, [6]; Leba, [15]; Nwandu [16]. In order to establish the linkages between the variables, the core of this research is to examine the relationship between economic variables and financial performance of listed firms manufacturing consumer goods.

\subsection{Statement of the Problem}

Firms operating in Nigeria especially those that are into production are facing various challenges ranging from: perennial increase in interest rate, high exchange rate and high rate of inflation among others due to the government lack of will power to create enabling environment. These variables impact negatively on firms' financial performance because it leads to increase in cost of operation, shortage of revenue and decline in assets base (net asset). The 2016-2017, 2018-2019 and 2020 recession that resulted to low inflows of foreign currencies due to drastic reduction stem from low oil prices and unfavorable exchange rate policy that resulted to forex pressures on manufacturing firms. The implication is that, since the banking sector experienced lower dollar inflows that resulted to borrowing of foreign currency by the 
government, firms getting dollars for transactions become more expensive thereby increase the cost of materials because of scarcity of dollars Egwuatu [17]. Manufacturing firms in Nigeria are battling the volatility of exchange, interest, inflation rates, inadequate funding of capital project by the government which has result to poor funding of modern assets because of the excessive increase in operational costs (Agu et al. [18]; Ogbole et al. [19].

\section{Literature Review and Theoretical Framework}

\subsection{Interest Rate}

Many scholars have defined interest rate using different meaning in order to convey meaning to the users of accounting information or financial data. Interest rate is that price paid for loanable funds which is sometimes determine by the forces of demand and supply Obura and Anyango, [20]. The reason of sourcing for loanable funds is to enable managers have a mix of capital structure that will enable them to have well balance gearing level for effective and efficient operations (Osoro and Ogeto, [21].

The cost paid for loanable funds is the finance costs charged by financial institutions or individual for the funds made available by the lender to the lendee who is normally based on percentage against the principal or the actual amount borrowed. Based on the neoclassical theory view point, the upshot of interest rate adversely affects the investment decision, thereby leading to a shrink in economic activities. The finance cost paid is the charged for borrowed funds for a geared firms and the cost can either impact on the firms involved either positively or negatively which will in turn affect investment decision (Olweny and Omondi [22].

\subsection{Inflation}

One economic variable that has continued to truncate or cause setback to many countries is inflation because during inflation, the value of money declines as the prices of goods and services increase (Maimunah and Patmati [23]. Since inflation affect profit and others performance variables like net asset, return on equity etc., the first point of reaction is from sales volume and also influencing the level of operating costs which also result to decline in the net asset per share and other variables Akabom-Ita, [24]. The resultant effect is that, the rise in inflation causes a decline in the value of currencies and this will affect companies that utilise local components or materials for production because more naira are used to purchase few components or materials. When the inflation rate is low, companies can still operate efficiently within a certain level, but high inflation impedes companies' performance because the price of inputs will skyrocket and the demand in the outputs will also reduce, and this will result to reduction in the annual revenue Meyers [25].

The rise in the level of inflation effect manufacturing sector in two ways; it can result to increase in sales or reduction depending how firms are able to manage the increase in the prices of materials used for production. Also, the rise in inflation affects the acquisition components and also the cost of exist within the market Nielsen [26]. The effects of inflation are not included in the nominal financial statements prepared by management, but the effects always caused consequences to the economic even during a period in which inflation is relatively low Ali [27].

\subsection{Exchange Rates}

This is simply the rate that a unit of currency that can be converted for another unit of currency between two countries. The change in the exchange rate is capable of affecting the price structure of an entity and the input procured for production. Normally, firms expect the monetary policy unit/department to ensure that there are well-articulated policies that will moderate the exchange rate in order not to result to excessive increase in the prices of imported input either goods, services or equipment. The appreciation in the naira is always a well come development because firms will pay less units of the naira for the dollar or pound depending on the country where the transaction occurs Kirui, Wawire and Perez, [28].

The cost of imported materials or components will reduce when the value of the home currency appreciate. Appreciation in the home currency enables firms that import some materials and services needed to keep operating activities going, especially local firms with less financial capacity to hedge foreign exchange risks (Kuwornu [29].

\subsection{Net Asset Per Share}

For any company, asset is the combination of equity and liabilities. By definition, the total assets controlled by a firm emanate from previous trading activities, there is expectation for value to be added to the firm total assets IFRS [30], while liability simply mean the financial debts that an entity owes third parties because of previous activities of the entity with third parties, from which settlements are made from the company financial assets or funds IFRS [30]. The Net worth or value of company is gotten by subtracting the company total assets from its total liabilities. Net asset value is very significant because without much analysis it shows if the company is liquid and will continue to be in business for unforeseeable future which is a core element of the going concern of all companies. Like the stock returns of firms, it is a function 
of the forces of demand and supplies based on investors' perception, as such, the returns add to the worth of entities Islam [11].

Net asset per share (NAPS) is an accounting variable used to express the worth of the net asset in relation to the total shares at the end of the accounting period. It shows how management is able to manage assets to generate the current worth which is a function of present resources controlled by entities. It is mathematically expressed as:

$$
\text { NAPS }=\frac{\text { Total assets }- \text { Total liabilities }}{\text { No. of ordinary shares }}
$$

\subsection{Financial Performance}

Financial performance encompasses elements in accounting literature, and for decade researchers have considered the sub elements or variables appropriate measure when evaluating the performance of corporate institutions/organizations small, medium and large Kaguri [31]. Company financial measures which are very conspicuous on the face of the financial statements are: EPS, NASP, ROA, DPS etc.; market performance measures are: sales, market share, etc; and shareholder return measured using ROE, dividend payout ratio, dividend cover etc. (Richard, Devinney, Yip, and Johnson [32] all these are metrics of measuring performance relating to different variables in the financial statements.

Lebans and Euske [33] clearly provide some basic concepts that better defined the term "performance". Performance comprises quantitative and qualitative measures which provide better explanation on how management is able to achieve set goals or objectives of their firms; and performance is a variable that contained sub variables that is used to evaluate management efficiency in the use of resources in creating value. It is dynamic, requiring herculean judgment using many metrics with the aid of accounting variables both quantitative and qualitative to measures if management is able to achieve set goals and how deviation may affect future plans.

\subsection{Fisher Effect Theory (1930)}

The supposition was developed by Fisher [34] based on some assumptions that in an economy, information concerning the expectations of inflation and interest rates are captured, and all market participants have access to all the information in the market. The first hypothesis relating to interest rate is supported by FET because the assertion of Fisher's is based on the assumption that economic activities result to changes in the movement interest rate. The assumption is valid but the real situation in Nigeria is that inconsistence in policy formulation and implementation sometimes negates this position of the FET. Fisher's, tries to critically examine the relationship between expected inflation, nominal interest and actual inflation rates in order to examine the effect on economic growth Chen [35]. Fisher is of the view that, all things being equal, the change of nominal interest and inflation rates will certainly affect a country currency and the deposit rate because a change in one will eventually result to change on another thereby influencing some sectors of the economy either positively or negatively. The obvious is that, the effect of interest rate can either be positive or negative (in favour of one company or negative to another company) depending on the movement of the interest rates. As such, managers are able to study the movement of interest rates using any available strategies before making investment decision in order to improve the operation of their entities. The essence of ensuring that inflation is well-manage, is to accelerate savings in bid to keep the economy activities under control Laichena and Obwogi, [36].

The expectation that nominal interest rate affects financial assets due to the fact that the movement of interest rate also move with inflation rate which is valid because inflation is capable of causing changes in the performance of entities. In a nutshell, when there is any alteration that will cause a shift either in a positive or negative direction, the long-term and short-term rates are expected to move in reaction to the market noise and this will equally determine the discount rate that firms will allow for their stocks (Kuwornu, [29]. The FET stated that the real and monetary sector rates do not have any relationship. This assumption in real life situation might not hold because when there is a shift in the monetary policy rate, there is that tendency that the real rate will shift since a rise or decline in the monetary policy rate will determine the direction of the real rate in the open market. The true situation of interest rate in Nigeria is that a rise in interest rate result to decrease in performance because many firms have gone moribund or reporting negative profit which has adversely affected the asset base of the entities.

\subsection{Inflation Theory}

The theory of inflation was first propounded by William in [37], and various opinions have emanated from economists in respect of inflation theory due to the different views of two schools of thought, namely, "monetarists and structuralists". Monetarists are of the view that inflation occurs as a result of monetary causes within an economy and suggested that for monetary policies to be adequately managed and controlled, there should be measures geared towards managing the inflation rates. Structuralists opined that inflation occurs as a result of lack of clear policies and unbalanced economic system and to proffer solutions to the persistent economic imbalance, they used both monetary and fiscal measures as instruments to check the economic situations. The third 
hypothesis was anchored on this theory because from the view of the two school of thoughts, they all pointed to lack of clear economic policy which is what the hypothesis addressed using firm performance variable to examine the effect.

The third hypothesis was anchored on this theory because from the views of the two school of thoughts, they all pointed to lack of clear economic policy which is what the hypothesis addressed using firm performance variable (net asset per share) to examine the effect of inflation. Inflation cause to a rise in consumer price index because the end users are the burden bearer since increase in cost is shifted from the producers to whole sellers and retailers, and finally the consumers. In relation to the Nigeria economic situation, periods of inflation have always been a period when the citizens spent more and it has been a recurrence situation. The changes in the price of items are sometime double or more than the actual price. When there is excessive rise in the value of consumables and non-consumables increase, the price of goods and services are skyrocketed which eventually cause decrease in the purchasing power of currency. Inflation can cause adverse effect on firm's profitability due to its effect on the cost of inputs Meyers [25].

The economic environment based on the government policies can help mitigate the effect of inflation when the government policies are geared towards finding lasting or palliative measures to reduce the effect of inflation on corporate firms. During the period of inflation those firms that experienced high demand may be able to mitigate the effect of inflation by increasing the prices of their products so that their profit margins are not altered. It also applicable to companies in a sector with low competition or where a firm has monopoly Meyers [25].

\subsection{Dynamic Theory of Profit}

The supposition by Clark in [38] is based on the assumption that, profit increases in a dynamic economy due to changes in some factors which is function of firms' financial performance based on previous activities. He believes the difference between the cost of input and output result to profit/loss, and for this to happen there must be some changes in the economic environment where firms operate. The changes are factors that contribute to increase in the asset thereby increasing the net asset per share (NAPS). Based on his assumption that profit is the outcome of dynamic changes, for such to occur, five generic changes must occur, which are: population is growing, changes in production system, increase in capital base, changes in industrial activities through advancement in technology, and consumer want are multiplying. The real situation is that for manufacturing firms to improve their activities or advance technologically, they must have strong assets that will aid such changes to occur. The dynamic changes will occur when factors in the economy are at moderate level whereby firms will have enabling environment that will encourage innovation in production and at the same time availability of capital to procure the needed assets for the innovation to take place.

For the five changes mention by Clark to take place, managers need to embrace the changes in the level of technological advancement and promote their businesses thereby reducing operating charges or cost of inputs, and in the same vein enhancing sales. Customers want are multiplying and population increase. When the changes as mentioned by Clark occurs as demand for the factors of production increases with corresponding increase in the prices of products, the changes as mentioned will result to increase in value added to firms' assets whereby the difference between assets and liabilities will result to increase in NAPS. Increase in production is aided by so many factors, and this can only be made possible through maximization of profit which is paramount among other objectives Damilola [39]; KPMG [40].

The increase in net asset depends on the amount of profit made at the end of the accounting period; this in turn enables managers to take advantage of business opportunities. The assumption that profit enhances effective and efficient allocation resources and suitable parameter to evaluate firms' performance is valid because it is a factor that determines the outcomes of many variables of financial indices Pandey [41]. The asset base of any entity increases because of the firm earnings, and also increase net asset per share. Profit is earned when the revenue generated in an accounting is higher than the costs of the input, which is function of the dynamic changes in the business environment. It is a dynamic element due to the fact that the word "profit" could be profit before tax, profit after tax, gross profit, net profit, profit per share, return on assets, among other variables Damilola [39]; Pandey [41].

\subsection{Purchasing Power Parity (PPP) Theory}

The PPP theory formulated by Gustav Cassel in [42] explained the rationale for the disparity between the exchange rate of one country and another. PPP is power of money expressed by the quantity of goods and services that one can purchase. The exchange rate between countries determines the strength of currency to another in terms of the purchasing power. The second hypothesis which deals with exchange rate is anchored on the PPP. Gustav assumption is that price adjustment of goods and services over a given period influence many factors in an economy. When this occurs firms spend more because of the rise in inflation and interest rates due to price differential also affect the exchange rate. The price difference is a function that determines the exchange rate, and the weaker currency will always suffer set back because more values are used in the open market for 
transactions. A practical situation is the current price of the dollar and Naira in which one dollar worth 515 Naira. The rise in the of commodities is primarily caused by inflation, which is a result of PPP between currencies, as such, the theory could be called inflationary theory due to the fact that when the prices of items skyrocket, the effect result to change in the development exchange rate. The exchange rate also results to price increase considering the situations for decades whereby the Naira hardly appreciate, rather the depreciation of the Naira continues to cause big gap between the two currencies which is commonly used for international transaction.

According to Coakley et al. [43] local currencies ought to have the capacity to procure some goods or services competitively if the country monetary authority has good policy that keeps the currency in the open market competitively. The strength of the exchange rate is a function of structure in an economic, because a good system with clear policies will always work together by ensuring that all the components work together to achieve common goal.

\subsection{Review of Empirical Studies}

Ruhomaun, Saeedi and Nagavhi [44] research on the effects of selected macro \& micro economic variables on firm performance for listed firms in the industrial products sector in Malaysia. The researchers made use of interest rate, exchange rate, financial distress and derivative activities as proxies for economic variables and Return on Asset and Return on Equity as proxies for performance. The study period is 5 years and the total sample was 196 . Panel data and generalized methods of moments (GMM) was used to examines the effect of the variables. It was concluded that all the variables have negative and insignificant effect on performance, exception of derivative that has significant effect on performance.

Ahmed, Muhammad, Sehrish, Sana, and Muhammad [45] research on the effect of economic variables on the performance companies in Pakistan. This study made used of secondary data which covered from 2002 to 2012 covering twenty companies from population of twenty-six companies listed in KSE. Panel data was used and the statistical technique was ordinary least square multiple regression. The variables used to measure performance are: leverage, sales growth, size, and age. The panel data analysis, the parameters used as proxies for microeconomic indicated that there is significant effect on ROA. Leverage has positive effect on the performance of the firms when ROA is analysed. Size age and growth have a positive impact on return on ROE.

Islam [11] research on the impact of inflation on growth of net assets of listed companies in Bangladesh: A Study on DS30 Companies. The total sample used is 30 companies listed on Dhaka Stock Exchange. The researcher did a comparison of the beginning net asset and ending net asset, taken into consideration the inflation rate in which each company net assets were adjusted with reporting data inflation rate. It was concluded that inflation has impact on the growth of net asset.

Issah, and Antwi [46] researched on the role of macroeconomic variables on firms' performance: Evidence from the UK. The essence of the study was to investigate how economic variables affect the ROA in order to predict the base performance. The statistical tools used are the principal component analysis and multiple regressions to evaluate the model. The total sample is of the study is 116 firms which covered from 2002-2014 excluding financial firms and regulated utilities due to the nature of their financial ratios. Each sample of the study had at least five years' financial data. The result shows high level of correlation between the variables, and the researchers concluded that firm should be taken into consideration when predicting firms' performance.

Owolabi [47] conducted research on economic characteristics and financial performance of selected manufacturing firms listed on NSE. The study used secondary data with the aid of some accounting performance indices like; ROA, EPS, ROE and Tobin's Q and economic indices such as; Inflation, Government Expenditure, Interest, Exchange Rates. The total sample size used is 45 listed companies on NSE., and out the 45, twenty-six (26) firms are into the production of consumer goods and nineteen (19) produce industrial goods. They used Ex-post facto research design. The results indicate that the variables used to measure economic characteristics have influence on the performance indices at different level. Interest, inflation, exchange rates and Government expenditure has strong effect on ROA and EPS., but the results showed no significant effect on ROE.

Umar, Jaleel and Shamshair [4] did a study titled "Do the macroeconomic factors influence the firm's investment decisions"? A generalized method of moments (GMM) approach. The researchers investigate 12 Asian countries in which the study covered 10 years, and the method of analysis is the GMM approach which was used to explore the linkage between macroeconomic factors and firms' capital investment. Based on the results of the study it was concluded that a rise in inflation result to decrease in investment due to increase in future cost of investments. Also, increase in interest rate result to decrease in capital investment thereby affecting the firms' asset base. Also, countries with good GDP have opportunities for increase in capital investments, but countries with high FDI experienced fierce competition, and bear the low investment chances. Akabom-Ita [24] research on effect of interest rate on the net assets of multinational businesses in Nigeria. Ex-post facto research design was used and variables were collected from CBN statistical bulletin and the firm's annual reports. The total population was sixty-three companies, and random sampling technique was used to pick a sample of seven companies. Net assets 
measured using net asset value Index. Based on the regression analysis it was concluded that increase in interest rate results to decline in net assets.

Research gap: many literatures were reviewed, and the researchers discovered that despite the extensive works on economic indices on performance, one key variable, Net Asset Per Share (NAPS) that is very conspicuous on the face of the financial statements has not been analyzed by researchers. The essence of using firms producing consumer goods is because individuals and corporate organizations spend more during inflation on consumable products, and it is the first study specifically measured impact of exchange, inflation, and interest rates on the performance of companies producing consumer goods in Nigeria using net asset per share as a proxy variable to measure performance.

\section{Research hypotheses development,}

1. Ho: Interest rate does not affect the Net Asset Per Share (NAPS) of companies producing consumer goods listed on NSE;

2. HI: Interest rate does have affect the Net Asset Per Share (NAPS) of companies producing consumer goods listed on NSE

3. Ho: Exchange rate does not affect Net Asset Per Share (NAPS) of companies producing consumer goods listed on NSE;

4. Ho: Exchange rate does have affect Net Asset Per Share (NAPS) of companies producing consumer goods listed on NSE;

5. Ho: Inflation rate does not affect Net Asset Per Share (NAPS) of companies producing consumer goods listed on NSE.

6. Inflation rate does have affect NAPS of companies producing consumer goods listed on NSE.

\section{Materials and Methods}

Since the research examine effect of interest, exchange and inflation rates on the NAPS of firms manufacturing consumer goods quoted on the Nigerian stock market, the researchers use Ex-post facto research design because direct control of the variables is not possible. The researchers merely study the effect of explanatory variables in retrospect to establish relation to, and the effect on the dependent variable. Ex-post facto design was considered more suitable since it is panel data and it enables the researchers to determine, evaluate and explain past events which are relevant for better and more reliable prediction of the future outcomes of the variables under study. The population of the study is twenty (20) manufacturing firms that are producing consumer goods, but four (4) firms from the twenty are outside the scope of the base study. The total sample size utilized is thirteen (13) firms selected using purposive sampling technique and elimination method was used to remove firms that were not listed within the period covered by the study.

The data for the study was gotten from Central Bank of Nigeria statistical bulletins and the firm's annual reports for the various years from 2004-2020. As such, companies outside this scope were not used. Ordinary Least Square (OLS) multiple regression analysis and other econometric tests such as: Augmented Dickey-Fuller test of unit roots, lag length, ARDL bounds test, long run and short run coefficients ARDL, Normality Test and Heteroscedasticity Test were the estimation techniques that were employed in determining the effect of interest, exchange and consumer price index rates on net asset per share (NAPS) of companies producing consumer goods.

\subsection{Model Specification}

The model is formulated in relation to the dependent variable denoted by $\mathrm{Y}$, which represents financial performance variable, and the explanatory variables $\mathrm{X} 1$, $\mathrm{X} 2, \mathrm{X} 3$ which represent the interest, exchange, and consumer price index. The inflation was measured using consumer price index. The model is mathematically stated as;

$$
\mathrm{FPI}=\mathrm{f}(\mathrm{IntR}, \mathrm{ExcR}, \mathrm{CPI})
$$

This equation (1) is written in a stochastic form as expressed below;

$$
\begin{gathered}
\mathrm{Y}=\mathrm{B} 0+\mathrm{B} 1 \mathrm{X} 1+\mathrm{B} 2 \mathrm{X} 2+\mathrm{B} 3 \mathrm{X} 3+\mathrm{e} \\
\text { Where } \mathrm{Y}=\mathrm{FPI}=(\text { Net Asset Per Share }) \\
\mathrm{X} 1-\mathrm{X} 3=(\text { IntR, ExcR, and -CPI, }) .
\end{gathered}
$$

$\mathrm{B} 0=$ the intercept for $\mathrm{X}$ variables in the regression model. B1, B2, and B3 = Coefficient of the independent variables. $r=$ stochastic error. Specifically, when the researchers converted the equation mathematically into:

$$
\mathrm{NAPS}=\mathrm{B} 0+\mathrm{B} 1 \mathrm{ExcR}+\mathrm{B} 2 \mathrm{IntR}+\mathrm{B} 3 \mathrm{CPI}
$$




\section{Data Analysis and Results}

\subsection{Results and Discussion}

Table 1. Summary Regression Results

\begin{tabular}{ccccc}
\hline Variable & Coefficient & Std. Error & t-Statistic & Prob. \\
C & 33.79248 & 35.86408 & 0.942237 & 0.3633 \\
CPI & 11.53354 & 3.511388 & 3.284610 & 0.0059 \\
INTR & -1.106464 & 2.502056 & -0.442222 & 0.6669 \\
EXCR & -0.488028 & 3.426800 & 1.421458 & 0.1787 \\
\hline
\end{tabular}

Source: Researcher computation, 2021

R-squared 0.803301; Adjusted R 0.757909

F-statistic17.69693 pro.(F-statistic) 0.000071

DW Stat 0.487595

From table 2 ordinary least squares result showed that the constant term entered the model with positive sign of 33.79248. The implication is that NAPS could increase without the effect of the explanatory variables. Estimated result, CPI has a positive relationship with NAPS. This means that a $1 \%$ rise in CPI leads to $11.5 \%$ improvements on NAPS. This is in line with the view of some scholars, because firms adjust their profit margin in order to cushion the effect of inflation which might lead to increase in profit margin. The results showed that CPI has p-value of 0.0059 less than 0.05 which indicates significant effect on NAPS. This result clearly affirmed the situation Nigerians experienced during the period of inflation whereby prices of goods are skyrocket beyond the expectations of the end users.

Interest rate from the result is negatively related to NAPS. This result indicates that an increase in interest rate by one per cent will result in 1.11 per cent decrease in NAPS. This result clearly affirmed the bemoaning of the manufacturers about the high interest rate due to lack of clear policy to control interest rate in Nigeria. Interest rate is not significant at $5 \%$ level of significance because the $p$ -value is 0.6669 is greater than the 0.05 . Also, exchange rate has a negative relationship with NAPS. By implication, a rise in the value of exchange rate by $1 \%$ could lead to corresponding 0.49 decrease in the value of NAPS. Exchange rate showed no significant effect on NAPS because the $\mathrm{p}$-value of 0.1787 is higher than the $5 \%$ level of significant set by the researchers.

The R-Squared showed that the explanatory variables in model accounted for 80.33 per cent of the variation in the value of NAPS, while the remaining 19.69 was accounted for the stochastic error term or other variables not captured in the model. The Adjusted- $\mathrm{R}^{2}$ value of $75.79 \%$ indicates that there is goodness of fit which is an indication that the data fit the model. The value of the FStatistic is 17.69693 (prob. Value 0.000071) is greater than the table value of 2.53 at $5 \%$ level of significant is an indication that all the variables used in the model has significant effect but at different magnitude. The value of 0.487595 of the Durbin - Watson statistics indicates that the model is in the region of positive autocorrelation.

The Augmented Dickey-Fuller (ADF) Test of Unit Roots test was used to test the stationarity of the behaviours of the dependent and the independent variables as depicted in table 3 showed that only consumer price index (CPI) was stationary at level because its ADF computed value of -3.902248 is greater compare to ADF critical value at 5 per cent. The other variables namely, NAPS, INTR, and EXCHR were all found to be stationary at first difference since their ADF computed values of ( -1.984520), (-3.768836), and (-3.177502) are all higher compare with ADF critical value at 5 per cent level. These are indications that the variables used in the model are good since the levels of stationarity are integrated of order zero and integrated of order one.

Table 2. Augmented Dickey-Fuller Test of Unit Roots

\begin{tabular}{|c|c|c|c|c|}
\hline Variables & $\begin{array}{c}\text { t-statistics: } \\
\text { Level \& } \\
1^{\text {st }} \text { diff. }\end{array}$ & PP Critical 5\% & Order of Integration & Remark \\
\hline NAPS & $\begin{array}{c}-1.050204 \\
(-1.984520)\end{array}$ & $\begin{array}{l}(-3.065585) \\
(-1.966270)\end{array}$ & $\mathrm{I}(1)$ & Integrated of order one \\
\hline INTR & $\begin{array}{c}-1.971025 \\
(-3.768836)\end{array}$ & $\begin{array}{c}(-3.065585) \\
(-3.081002)\end{array}$ & $\mathrm{I}(1)$ & Integrated of order one \\
\hline CPI & -3.902248 & $(-3.098896)$ & $\mathrm{I}(0)$ & Integrated of order zero \\
\hline EXCR & $\begin{array}{c}0.609458 \\
(-3.177502)\end{array}$ & $\begin{array}{c}(-3.065585) \\
(-3.081002)\end{array}$ & $\mathrm{I}(1)$ & Integrated of order one \\
\hline
\end{tabular}

Computation by researchers, 2021

Table 3. Lag length selection criteria

\begin{tabular}{ccccccc}
\hline Lag & LogL & LR & FPE & AIC & SC & HQ \\
0 & -233.6795 & NA & $6.56 e+09$ & 33.95422 & 34.13680 & 33.93731 \\
1 & -163.5552 & $90.15978^{*}$ & 3276817. & 26.22218 & 27.13512 & 26.13767 \\
2 & -132.6403 & 22.08213 & $892091.6^{*}$ & $24.09146^{*}$ & $25.73475^{*}$ & $23.93935^{*}$ \\
\hline
\end{tabular}

Source: researchers' computation, 2021. 
The aim of the lag length test in table 4 is to enable the researchers choose the highest lag length that variables would be lagged. As such, many lagged length were adopted which include: sequential modified LR test statistics, Final prediction error, Akaike information, and Hannan-Quinn information, and Schwarz information criterions. The results as revealed in table 4.4. Lag length of two (2) were chosen based on the Akaike information criterion, Schwarz information criterion, and Hannan-Quinn information criterion.

Table 4. ARDL Bounds Tests for the Existence of co-integration Null Hypothesis: No long-run relationships exist.

\begin{tabular}{ccc}
\hline $\begin{array}{c}\text { Test Statistic } \\
\text { F-Statistic }\end{array}$ & Value & K \\
\hline & 2.739784 & 3 \\
\hline Significance & I0 Bound & I1 Bound \\
$10 \%$ & 2.72 & 3.77 \\
$5 \%$ & 3.23 & 4.35 \\
$2.5 \%$ & 3.69 & 4.89 \\
$1 \%$ & 4.29 & 5.61 \\
\hline
\end{tabular}

Source: researchers' computation, 2021.

Null Hypothesis: No long-run relationships exist. The bounds test for the existence of co-integration in table 5 showed that the F-statistic value is 2.739784 is lower when compared with the lower and upper bounds of 3.23 and 4.35 the critical values at 5\% using Pesaran et al [48]. Based on the results of the test, the Ho of no co-integration is accepted. No existence of long run relationship between NAPS, INTR, EXCR and CPI.
Table 5. The Short Run Coefficients ARDL

\begin{tabular}{ccccc} 
Dependent Variable: NAPS & & & \\
\hline Variable & Coefficient & $\begin{array}{c}\text { Std. } \\
\text { Error }\end{array}$ & t-Statistic & Prob. \\
D(CPI) & -4.456828 & 19.498538 & -0.338572 & 0.82668 \\
D(CPI(-1)) & 37.367230 & 14.762718 & 2.531189 & 0.0446 \\
D(EXCHR) & -0.1688880 & 0.302957 & -0.557440 & 0.5974 \\
D(INTR) & 2.804853 & 2.053921 & 1.365609 & 0.2210 \\
D(INTR_(-1)) & 3.892208 & 1.787808 & 2.177084 & 0.0724 \\
ECM(-1) & -0.155982 & 0.214402 & -0.727520 & 0.0443
\end{tabular}

Source: researchers' computation, 2021.

The results of the short run coefficient ARDL in Table 6 showed that CPI and INTR are significant at 5 and 10 per cents respectively meaning that only one-year lag values of CPI and INTR seem to impact significantly on NAPS in the short run. The present values of INTR as well as one-year lag values of INTR and CPI indicate positive coefficients. The implication is a one per cent rise in the short run, could lead to a rise in the present values of INTR, CPI as well as one-year lag values of INTR and CPI increases NAPS by 2.80 per cent, 3.89 per cent, and 37.37 per cent. Also, present values of consumer price index and exchange rate indicate negative coefficients. The implication is that a rise of one per cent in present values of consumer price index and exchange rate reduces NAPS by 4.46 , and 0.17 per cents in the short run. Also, ECM coefficient showed good sign because it is negative. It is an indication of slow speed of adjustment of 21.44 per cent.

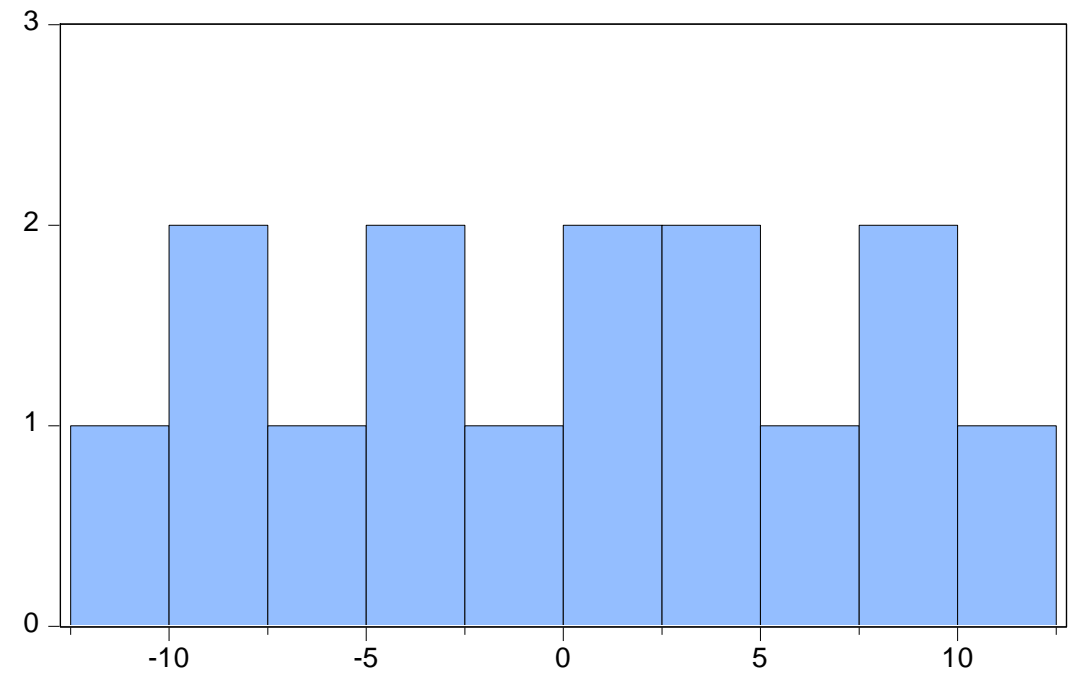

H0: Residual is multivariate normal H1: Residual is not multivariate normal Significance if $\mathrm{p}$-value $>0.05$

\begin{tabular}{|c|c|}
\hline \multicolumn{2}{|c|}{$\begin{array}{l}\text { Series: Residuals } \\
\text { Sample } 20042020 \\
\text { Observations } 15\end{array}$} \\
\hline Mean & $7.34 e-14$ \\
\hline Median & 1.005917 \\
\hline Maximum & 12.08414 \\
\hline Minimum & -11.65298 \\
\hline Std. Dev. & 7.091636 \\
\hline Skewness & -0.061079 \\
\hline Kurtosis & 1.910886 \\
\hline Jarque-Bera & 0.750683 \\
\hline Probability & 0.687055 \\
\hline
\end{tabular}

Figure 1. Testing of normality 
The Jacque-Bera statistic test for the goodness-of-fit of data, and based on the result, the value is 0.750683 with prob. value of 0.687055 that is higher compare with the 0.05 levels. Consequently, the $\mathrm{H}_{\mathrm{O}}$ was accepted which stated that the residual is normally distributed since there is indication that the date has skewness and kurtosis expected of normal distribution provided that the residual is stationary.

Table 7. Breusch-Pagan-Godfrey serial Auto-Correlation LM test H0: there is no serial correlation

\begin{tabular}{cccc}
\hline F-statistic & 0.270211 & $\begin{array}{c}\text { Prob. F(11,2) } \\
\text { Prob. }\end{array}$ & 0.9410 \\
Obs*R-squared & 8.368832 & $\begin{array}{c}\text { Chi-Square(11) } \\
\text { Prob. }\end{array}$ & 0.6799 \\
$\begin{array}{c}\text { Scaled explained } \\
\text { SS }\end{array}$ & 0.106320 & $\begin{array}{c}1.0000 \\
\text { Chi-Square(11) }\end{array}$ & \\
\hline
\end{tabular}

Source: Researchers Computation, 2021

The Breusch-Pagan-Godfrey test which was used to the assessed the validity of the assumption of the model if there is any error in the regression showed that the results in table 7 for the residual auto-correlation value of 0.6799 of the Chi- square are greater than $5 \%$. The H0 was accepted which state that there is no serial auto-correlation. By this we affirmed that the data used for the analysis are not victimized by serial correlation throughout the series. This implies that the regression model fit the data and has predictability capacity based on the conclusion reached by the researchers.

\subsection{Discussion of Findings}

The findings of this study are very promising, and based on the econometric variables used for the study, it was discovered that there is positive relationship between the dependent variable and the explanatory variables based R- square and adjusted R-square values. The t-test show that CPI has a significant effect on NAPS at $5 \%$, but IntR and ExcR do not have significant effect at within the $5 \%$ threshold, and the F-statistic also indicates that the entire variables have significant effect on the dependent variable. The work of Obeng-Krampah [49] noted that interest and inflation rates have negative effect on firms' performance both ROE and ROA. The results are in line with economic predictions about the effect of interest and exchange rates on firms' performance. The view of the researchers is; interest and exchange rates result to decline in the performance of firms, and this has been empirically analyzed. It was also discovered that CPI has a short run relationship and has significant effect on NAPS at $5 \%$, but other variables do have significant effect on NAPS, which is consonant with result of OLS. No long-run relationship based on the co-integration test between the variables used. Also, the study of Akabom-Ita [24] on the impact analysis of interest rate on the net assets of multinational businesses in Nigeria deduced based on the findings that increase in interest rate result to decline in net asset value Index of multinational businesses in Nigeria.

\subsection{Conclusion and Recommendations}

The Nigeria economy is going through turbulent phase due to bad economic policies that negatively affected the Nigeria economy which in turn caused negative impact on operating activities of manufacturing companies in Nigeria which emanates from lack of well-articulated and poor implementation policies. For decade the sector has been contending with the unbearable economic challenges, while the government has made various economic policies that have failed to address the problems. The results of the various test that were analyzed to examine the effect of the economic indices on the performances index (NAPS) are in line with the opinion of researchers that increase in interest and exchange rates result to decline in financial assets of companies.

Empirically, this article provided evidence that upward movement of interest rate result to decrease in the financial assets of firms because the increase in finance costs result to in drop in revenue which is in line with the work of Umar, Jaleel and Shamshair [4]. Exchange rate also decreases the financial assets of firms because more naira is used as exchange for a dollar or pound. This result to increase in costs and decrease in firms' assets because many firms report negative profit after paying for operational costs. All the independent variables show that there is positive correlation, but exchange and interest rates does not have significant effect on financial performance of manufacturing firms in Nigeria. Consumer price index has significant effect on NASP and it is in line with economic reality as the increase in materials result to increase in production cost, the prices of products are adjusted to cushion the effect of the increase in raw materials used for production. The practical implication is that consumers are at disadvantage because the margin that firms factor in due to increase in costs are shifted to the whole sellers, and the retailers, but the end users are the burden bearer because in Nigeria period of inflation is an opportunity for price increase which sometimes remained static for months without any adjustment to reflect the current change in economic situation. The findings of this study are very promising because Nigeria economic is going through turbulent phase that almost all sectors of the economic is in total disarrayed because of the worsening economic situation due to COVID-19. The findings have shown that Nigeria economic team need to address the issue of exchange rate and interest rate in order for the prices of consumables products to go down. If the two issues are well managed, consumer price index will certainly reduce.

\subsection{Recommendation}

The theoretical foundation of Fisher Effect Theory has not completely solved the issues of inflation and interest because the assumption of market capturing the effect of interest rate enables the government to relaxed 
implementation and monitoring of policies. Based on this, the government should make policies that provide moderate interest rate for some materials/assets for manufacturing firms to increase their performance thereby contributing more to their assets.

There is need for the government to apply the view of monetarists and structuralists based on the theory of inflation. The increase in inflation measured using consumer price index occurs as result failure on the part of the government, as such, polices should be formulated and implemented in line with view of the two school of thoughts with the aim of curtailing the rise in inflation rate, so that consumers are not affected or increase their spending on the consumption of domestic products.

Also, to reduce the rate of demand for foreign products to strengthen the naira, there is need for the Government to critically examine the purchase power parity based PPP theory because the exchange rate between the naira, dollar and pound, is a call for the government encourage the patronage of made in Nigeria, and export of local products because many times the depletion in foreign reserve resulted to scarcity of dollars which is one of the common foreign currency used for international transactions by firms.

The increase in exchange rate is a worrisome situation to all firms, to assuage the negative effect, there is need to address the problem, of inflation and interest because both are closely related, and upward movement could cause exchange rate to soar. Companies should put in place mechanisms to control their foreign exchange exposures majorly transaction risks using the various techniques available. To achieve good result, it depends on how proactive managers are in monitoring the changes in the economy specially market indices. Also, on the part of the government, policies should be made to mitigate the excessive exchange rate fluctuations and intervention should be made available if the foreign exchange risks affect the productive sector.

\section{REFERENCES}

[1] Sanusi, L.S. “Growing Nigeria's real sector for employment and economic development: The role of Central Bank of Nigeria". Paper delivered at the inaugural memorial lecture in honour of late Professor Okefie Uzoaga at the University of Nigeria, Enugu Campus, 2011.

[2] World Bank Group. "Kenya economic update." available at: www.wds.worldbank.org/external/default/WDSContentSer ver/WDSP/IB/2015/10/14/090224b0831443e/1_0/Rendere d/PDF/Kenya0economic0public0participation.pdf, 2015.

[3] Broadstock, D.C., Shu, Y., Xu, B. "The heterogeneous impact of macroeconomic conditions on firms' earnings forecast," Proceedings of Macao International Symposium on Accounting and Finance, Macao, 2011.
[4] Umar, F.; Jaleel, A., Shamshair, K. "Do the macroeconomic factors influence the firm's investment decisions? A generalized method of moments (GMM) approach." International Journal of Financial Economics, vol. 26, pp.790-80, 2020. DOI: 10.1002/ijfe. 1820

[5] Oso, T. "Cite disruption of raw materials to food manufacturing segment by insecurity as a Problem", June, 2021.

[6] Agubata, S. and Odubuasi, A. C. Effect of exchange rate fluctuations on the financial performance of Nigerian manufacturing firms. International. Journal of Commerce and Management Research, Vol. 2, pp.56-61, 2014.

[7] Ogunbiyi, S. S., Ihejirika, P. O. "Interest rates and deposit money banks' profitability nexus: The Nigerian experience, Arabian", Journal of Business and Management Review Vol.3, no.11, pp.133-148, 2014.

[8] Adebiyi, M. A. "Can high real interest promote economic growth without fueling inflation in Nigeria". Journal of Economic and Social Studies, Maiden Edition, pp.80-100, 2001.

[9] Rasheed, O.A. "Interest Rate Determinants in Nigeria. International Journal of Finance and Economics", vol. 2 no.3, pp.1-12, 2008.

[10] Okafor, F.O. "Micro-Credit: An instrument for economic growth and balanced Development". African Banking \& Finance Review. Vol.1 No.1, pp.31 - 42, 2012.

[11] Issah, M., Antwi, S. (2017). "Role of macroeconomic variables on firms' performance: Evidence from the UK". Cogent Economics \& Finance, pp. 1-18. https://doi.org/10.1080/23322039.2017.1405581.

[12] Onakoya, A.B. (2014). "Contributions of manufacturing in the context of inter-sectoral linkages to economic growth in Nigeria”. Journal of Social and Behavioural Sciences, Vol.3 no.1, pp.81-105, 2014.

[13] Amakom, U. "Manufactured exports in Sub-Saharan African economies: Econometric tests for the learning by exporting hypothesis". American International Journal of Contemporary Research, Vol.2 no.4, pp.195-206, 2012.

[14] Mintzberg, H., Lampel, J., Quinn, J. B. "Ghosal, S. "The strategy process: concepts, contexts, Cases" (4th ed.) Essex: Pearson, 2012.

[15] Leba, "Inflation: The quiet plague", Financial Vanguard, February 13:31, 2012.

[16] Nwandu, E. "Impact of Rising Interest Rate on the Performances of the Nigerian Manufacturing Sector." European Journal of Business and Management. Vo 18, no.10, pp.125-134, 2016.

[17] Egwuatu, P. Nigeria: renewed foreign currency shortages highlight vulnerability for banks"Liquidity-nigerian-banksvulnerable-moodyswarns $\% 2 \mathrm{~F} \&$ identifier=https $\% 3 \mathrm{~A} \% 2 \mathrm{~F} \%$ 2Fwww.vang, 20-11-2020.

[18] Agu, S.U., Idike, A.N., Okwor, I.M.I, Ugwunta, D. "Fiscal policy and economic growth in Nigeria: Emphasis on various components of public expenditure", Singaporean Journal of Business Economics, and Management Studies, vol. 2 No. 12, pp.37-54, 2001. 
[19] Ogbole, F.O., Amadi, S.N., Essi, I.D. "Fiscal policy: its impact on economic growth in Nigeria (1970-2006)", Journal of Economics and International Finance, vol.3 no.6, pp.407-417, 2011.

[20] Obura, J. M., Anyango, C. "Moderating effect of interest rates on relationship between Foreign exchange rate fluctuation and performance of Nairobi Securities Exchange Market". Universal Journal of Accounting and Finance, vol.4 no.2, pp.27-34, 2016.

[21] Osoro C. and Ogeto W. "Macroeconomic fluctuations effects on the operational Efficiency of listed manufacturing firms in Kenya". International Journal of Social Sciences, vol.21 no.1, pp.26 39, 2014.

[22] Olweny, T., Omondi, K. "The Effect of Macroeconomic Factors on Stock Return Volatility In the Nairobi Stock Exchange, Kenya.” Economics and Finance Review, vol.1 No.10, pp.34 - 48, 2011.

[23] Maimunah, A., Patmawati, I. "Inflation and companies' performance: a cross-sectional Analysis". Journal of Computational and Theoretical Nanoscience, vol.2, pp.1-18, 2018.DOI:10.1166/asl.2018.11694.

[24] Akabom-Ita, A, Impact Analysis of Interest Rate on the Net Assets of Multinational Businesses in Nigeria. Research Journal of Finance and Accounting, vol.3, no. 7. 71-77, 2012.

[25] Myers, S. C. "Capital structure. Journal of Economic Perspectives”, vol.15 no.2, pp.81-102, 2001.

[26] Nielsen, K. M. "The return to direct investment in private firms: New evidence on the private equity premium puzzle", European Financial Management, vol.17, no.3, pp.436-463, 2011.

[27] Ali, C D. A. "Relationship between inflation and firms' performance evidence from Nigeria". World Applied Sciences Journal, Vol.33 no.5, pp.814-822, 2015.

[28] Kirui, E., Wawire, H. W., Onono, P. "Macroeconomic Variables, Volatility and Stock Market Returns: A Case of Nairobi Securities Exchange, Kenya". International Journal of Economics and Finance, Vol.6 no.8, pp.214-228, 2014.

[29] Kuwornu, J. K. M. "Effect of Macroeconomic Variables on the Ghanaian Stock Market Returns: A Co-Integration Analysis". Agris on-line Papers in Economics and Informatics, Vol.4 No.2, pp.1-12, 2012.

[30] IFRS. "Conceptual Framework for Financial Reporting. IFRS Foundation", 2015.

[31] Kaguri, W.A. "Relationship between firm characteristics and financial performance of life insurance companies' in Kenya", unpublished master's thesis, University of Nairobi', 2013.

[32] Richard, P.J., Devinney, T.M., George, S.Y., Johnson, G. Measuring organizational Performance: Towards Methodological Best Practices, Journal of Management, Vol.35, pp.718-804, 2009.

[33] Lebans, M., Euske, K. "A conceptual and operational delineation of performance, business performance measurement, Cambridge University Press, Cambridge, pp.65-79, 2006.

[34] Fisher, I. The Theory of Interest, Macmilla, New York, 1930.

[35] Chen, M.X. "History of Economic Theory". China Renmin University Press, Beijing, 2003.

[36] Laichena, K. E. \& Obwogi, T. N. "Effects of Macroeconomic Variables on Stock Returns in the East African Community Stock Exchange Market.” International. Journal of Education and Research, vol. 3, no.10, pp.305-320, 2015.

[37] William, F. T. "A reconstruction of macroeconomics: problems of theory and policy." American, 1976.

[38] Clark, J.B. "The distribution of wealth," 1900.

[39] Damilola, D. A. (2007). "Corporate finance: issues, investigations, innovations and applications," (2nd ed) Lagos, H.R. P., 2007.

[40] KPMG, "Working Capital Management Survey: How European Companies manage their Working Capital". KPMG International. Retrieved on 15-03-2016.

[41] Pandey, I. M. "Financial Management." (10 $0^{\text {th }}$ ed.) V. P. H PVT. Ltd, New Delhi, 2008.

[42] Cassel, G., "Abnormal Deviations in International Exchanges," Economic Journal, vol. 28 pp. 413-15.

[43] Coakley, Jerry, Robert flood, Ana-maria. "The purchasing power parity debate 155 fuertes and mark." "long-run purchasing power parity and the theory of general relativity: the first tests." journal of international money and finance. vol.2. no.3, pp.12-27., 2004

[44] Ruhomaun, M. A Mitra, M., Nagavhi, N. "The effects of selected macro \& micro economic variables on firm performance for listed firms in the industrial products sector in Malaysia," International Journal of Recent Technology and Engineering, vol.7, no. 5 pp.95-110, 2019.

[45] Ahmed, I. H., Muhammad, I. C., Sehrish, J., Sana, N., Muhammad S. I. "Impact of micro economic variables on firms' performance.” International Journal of Economics and Empirical Research, vol. 2, no. 2, 65-73, 2014.

[46] Issah, M. \& Antwi, S. (2017). Role of macroeconomic variables on firms' performance: Evidence from the UK. Cogent Economics \& Finance, pp.1-18. https://doi.org/10. $1080 / 23322039.2017 .140558$

[47] Owolabi, B. A. "Economic characteristics and financial performance of selected Manufacturing companies' in Nigeria." An unpublished research submitted to Babcock University Ilishan-Remo Ogun State, 2017.

[48] Pesaran, H., Shin, Y., Smith, R. (2001). Bounds testing approaches to the analysis of level relationships. Journal of Applied Econometrics, vol.16 No.3, pp.289-326.

[49] Obeng-Krampah, D. K. 'The impact of macroeconomic factors on firm performance." 2018. URI: http://ugspace.ug.edu.gh/handle/123456789/27370. 